Markku Käpylä , PhD, Docent, is a university lecturer retired from the University of Jyväskylä. His research interests are biological and environmental education.

\title{
A phenomenological view of pictures in teaching and a novel method of analysing them
}

\author{
Abstract \\ In this paper a novel method for analysing the content and teaching potential of pictures is presented. \\ It is the four-field method, which is based on phenomenological thoughts about human experience, \\ which combines factual knowledge with emotions and personal and social meanings. A biological \\ example is given. Around this idea a course unit for using pictures in science teaching was organized. \\ It was used in the training of both primary and secondary level teachers. From picture analysis the \\ course unit proceeds to planning the use of pictures in teaching. A classification of the teaching func- \\ tions of pictures is presented.
}

\section{INTRODUCTION}

My long experience as a teacher educator tells me that pictures are rarely used in teaching in spite of their abundance in textbooks (see also Pozzer \& Roth, 2003) and "reading" of pictures is not explicitly taught. Student teacher's ability to use pictures for teaching purposes is poor. Perhaps teachers and students think that the ability to "read" pictures is inherent and easy (Solomon, 1984). However, the skill of picture comprehension develops as slowly as text comprehension and it must be deliberately taught (e.g. Pozzer-Ardenghi \& Roth, 2005). There are very few efforts to develop learning strategies from illustrations (Schlag \& Ploetzner, 2011). Almost without exception teaching is directed to learning predetermined content in a predetermined way. The emphasis is on factual content. This paper is an attempt to develop another way of seeing and using pictures in science education, which starts from the analysis of human experience and puts equal emphasis on the affective domain and personal and social meanings. This approach is more typical of humanities and humanistic environmental education (Knapp \& Goodman, 1983; Knapp, 1992). I hope that this approach will help teachers in the effective use of the pictures in teaching, and at the same time promote the integration of school subjects.

The pictures in science classes can roughly be divided into two categories (1) Representational pictures trying to present their object as it appears. (2) Symbolic pictures not resembling the external appearance of the object. There is a wide variety on picture types ranging from photographs and realistic drawings to schematic drawings and diagrams, but most textbook pictures are photographs or naturalistic drawings (Pozzer \& Roth, 2003). This paper mostly deals with naturalistic pictures.

The question of the effect of pictures in learning is complicated. Some studies show that learning from text alone has been more successful than learning from text and pictures (Hannus, 1996; Rasch 
\&Schnotz, 2009). Hannus (1996) even recommended that textbooks should only have a small amount of pictures and mostly schematic drawings. A third of the students in the study of Kearsey and Turner (1999) suggested a move away from the modern textbook to the more traditional format involving more line diagrams. In some other studies a general positive effect of pictures has been found (Reid 1990a). More detailed studies have shown that pictures increase comprehension if explained in the text, and that the content of pictures not explained in the text was not learned at all (Reid, 199ob; Hannus. 1996). Apparently pictures have a strong positive effect on recalling things, but not necessarily on understanding. Abstract concepts are learned rather from text than from pictures, and pictures do not necessarily promote learning concepts (Reid 1990a; 1990b; Rasch \& Snotz, 2009).

The effect of the pictures in teaching is also dependent on student cognitive ability. Above-average ability pupils benefit from pictures but among below-average ability students learning is impaired. Obviously pictures disturb concentration on the text in below-average ability pupils (Hannus, 1996; Reid, 1990b). A possible explanation is found in cognitive load theory: pictures mean an extraneous cognitive load, which means a decrease in working memory capacity (Cook, 2006). This happens when learners have to repeatedly search for text segments while analysing the picture (Florax \& Ploetzner, 2010). Also learning styles (e.g. visual and verbal learners) affect the way pictures are used in learning (Mayer \& Massa 2003).

There is a very considerable body of knowledge concerning the learning effects of different picture qualities. From an educational point of view one of the most important is colour. Colours definitely make pictures more interesting but do not necessarily promote understanding. More details are seen in coloured pictures even if qualities directly dependent on colour are excluded. An unwanted result is that colours often direct attention to details, which are not scientifically important (Reid, 1990a; Reid \& Miller, 1980). In many cases simplified line drawings promote learning better than detailed colour pictures.

The most important thing in explaining the variation of picture interpretations is the learner's prior knowledge (Cook, 2006). Other meaning making resources are the textbook text and teacher's talk. Picture and text interaction is very important in reading textbook pictures (Reid, 199ob). Main text and picture captions are a resource in making sense of the picture. These, however, do not guarantee that students will interpret the picture in the intended way (Pozzer-Ardenghi \& Roth, 2005). Hannus (1996) found that the details given only in the pictures were not learned at all, thus making it necessary to explain the picture in the text. To make meaning-making easier it is important to place text and pictures near each other (Florax \& Ploetzner, 2010) and that the picture caption gives guidance for reading and interpreting the picture (Pozzer-Ardenghi \& Roth, 2005).

The purpose of textbook pictures is in most cases clear. They illustrate or explain the main points of the factual knowledge given in a text chapter. In some cases pictures have no obvious educational purpose and are called merely decorative to quote Pozzer and Roth (2003). There might still be a good reason for using these pictures. Pictures immediately catch students' attention and this is one of the major functions of pictures in textbooks (Kearsey \& Turner, 1999; Pozzer-Ardenghi \& Roth 2005). Pictures thus seem to make the subject or topic more interesting. The teaching functions are usually divided into affective, e.g. increasing motivation, and cognitive, which makes understanding of the content easier. There are some attempts in the literature to classify the teaching functions of pictures (Hannus, 1996; Hatva, 1987; Pozzer \& Roth, 2003; Reid, 1990a) and in this paper I present my own attempt at classification.

The poor use of pictures by teacher students during their teaching practice frustrated me. I decided to develop a course unit to improve the use of pictures in teaching. Gradually a simple tool for analyzing pictures in planning teaching was developed. It is a four-field matrix based on the ideas of several scholars on human experience (Berleant, 2000, pp. 85-134; Karjalainen, 1986; Tuan, 1977; Wag- 
ner, 1983). The main purpose of this article is to introduce this fairly simple analytical tool with an example, and give guidelines for using of the results of picture analysis for planning the teaching. The course unit on the use of pictures was part of a science teaching course for primary teacher students. It was also included in a similar course for biology teacher students and in each case was taught as a small group practical (about 16 students) practical lasting 3-4 hours.

\section{A PHENOMENOLOGICAL VIEW OF SEEING THE PICTURE AND DEVELOPMENT OF THE}

\section{ANALYSING TOOL}

Learning phenomenology is fairly demanding and most science educators have ignored it. It follows that different thinkers use different terminologies and many ideas in phenomenology are contrary to everyday thinking. Phenomenological theory is given here as a minimum for understanding pedagogical application. Interested readers are directed to some textbooks (Berleant 2000; Moran 2000; Smith, Flowers \& Larkin 2009; Wagner 1983). Phenomenology studies human experience. "Everything for a man is experience" (Berleant, 2000: 85). I accept the wide definition by Tuan (1977, p. 8): "Experience is a cover-all term for various modes through which a person knows and constructs reality". The experience is mainly emotional; in Tuan's (1977, p. 9) words: "Emotion tints all human experience, including the high flights of thought". Emotion is quickly qualified as something to avoid or something to strive after. Feelings are thus intentional. In feeling intention and affection coincide in the same experience. Experience seems passive, but it means acting and learning (Tuan, 1977, p. 9).

Human experience is seen as a whole, bodily, and multi-sensory (Lefebvre 2002, p. 33; Pink, 2011). In experience the information of all the senses is fused. Sensory experience as such does not contain meanings, which are constructed in people's minds. However, what is perceived and understood depends on earlier knowledge and earlier experiences. Already existing mental models or cognitive schemata are activated (Seufert, 2003; Staver, 1998). Experience is also partly independent of time and place. Present sensual information is fused to memories of the past and images and hopes for the future. Present experience is also affected by memories and imaginations of other places, which might be imaginary as in religious experience.

Photograph is a caught moment in the continuous flow of time. In interpreting the picture this is helpful because it allows us to stand back and take a theoretical view. The spectators own life world is always the starting point of interpretations. What we see in the picture is affected by our past experiences, our existing knowledge structures and our world view. Many of the personal and social meanings, which we use to "read" the pictures, are not actually seen in the picture. According to Tuan (1979) perception and conception are a continuum in human experience. Seeing is an act of intellect, but to see further requires an additional effort of abstraction. People have to deliberately make a choice and exclude a mass of details to understand the main features and processes of the underlying reality. This means putting information within a larger context.

Experience is a whole, internal and external world and individual and social realities are inseparable (Adams, 1999). That is why this view is also called holistic. However, experience cannot be thought of as a whole. We can only analyze it one aspect at a time. Talking and writing about an experience is always a selection (Wagner, 1983). If we want to analyze an experience we have to divide it analytically into several layers or parts. Art historian Erwin Panofsky has been the most influential person to develop the idea of layers in the perception of pictures (paintings). His three layers (subject matter and meanings unified) are (Panofsky, 1972: 3-17): (1) Primary or natural subject matter, (2) Secondary or conventional matter: personifications, motives, images etc., (3) Intrinsic meaning of the content: the discovery and interpretation of symbolic values, the basic attitude of a nation, class or a period. Panofsky's ideas have influenced human geographers' view of landscapes (Karjalainen, 1986; Cosgrove \& Daniels, 1989). 
Karjalainen and Raivo (1995) divide landscape or environment into three layers of seeing: (1) The objective layer is formed by concrete objects; The subjective layer is our personal sensual experience and feelings elicited by the object; (3) The representative layer is formed by cultural meanings, messages and symbols. In this classification the objective subject matter is separated from personal and social meanings. The classification can be the same whether the object is real or a picture of it. This classification is very useful and informative in teaching and it is fairly easily understood by students. For many years I used this three layer classification in my teaching and I still consider it very fruitful. A somewhat similar three-layer classification is impersonal, personal, and interpersonal (see e.g. Mansour (2007).

Other classifications have also been used. In an educational context it is common to separate the cognitive and affective domains of an experience. Observations can be direct if immediately understood or indirect if understood only after the interpretation of cultural meanings (cf. Panofsky's third layer). With natural objects some knowledge structure must be used in order to make sense of the object.

After some years of thinking and trials in classroom I designed a four-field matrix, where the axes are direct / indirect and cognitive / affective observations. It was then noticed that the three layers of Karjalainen and Raivo (1995) can be placed onto a four-field matrix (Table 1). Objective (cognitive) content is divided into directly and indirectly observable parts, with the latter needing theorizing and interpretation. Direct affective refers to subjective sensual experience. Indirect affective refers to the representative layer, cultural aspects of seeing. Clearly these categories cannot be strictly separated, because all these function together and affect each other in an experience.

Table 1. The four-field method for analysing pictures.

\begin{tabular}{|l|l|l|}
\hline & Cognitive domain & Affective domain \\
\hline Direct observations & Directly observed objects and details & $\begin{array}{l}\text { Immediate feelings and attitudes } \\
\text { aroused by the picture }\end{array}$ \\
\hline Indirect observations & $\begin{array}{l}\text { Interpretations based on knowledge } \\
\text { structures }\end{array}$ & $\begin{array}{l}\text { Socially mediated attitudes, symbols } \\
\text { and meanings }\end{array}$ \\
\hline
\end{tabular}

The course unit was organized around the four-field-method. First the three-layer and the four-field methods were introduced. Then an exemplary analysis of the snail picture (se below) was done using class discussion. The use of the four-field analysis results in planning teaching was the next phase, where the results of the snail picture analysis were applied. The longest period of the course was spent on an application exercise, where students analysed a self-selected picture. The course unit ended with a short summary of the most important research findings on using pictures in teaching.

\section{EXEM PLARY ANALYSIS OF A PICTURE: THE VINEYARD SNAIL}

Let us take a fairly simple example, a picture of an animal, a snail (Fig. 1). I chose this picture because of its relative simplicity, and because a picture of the whole animal or plant is a typical biological picture in primary school and lower secondary school textbooks and teaching. The vineyard snail is a type of animal commonly used in biology teaching.

A simple way to introduce students to some principles of seeing is to ask them to list the items and details they see in the picture (Table 2). The number of picture details listed varied from 5 to 15 , average 10.o. The frequency of observation and the order of items in the list provide good material for the discussion of human picture reading. The results of 50 primary school teacher students are given in Table 2. In many cases students did not know the correct names of the animal parts, but it was usually easy to guess what they meant. No one mentioned the head or the tail, which is understandable, because 
these parts are not clearly separated from the body. Only one of the lower pair of tentacles is visible in the picture, which is why many students supposed it to be some kind of snout. Many named the knobs at the end of longer tentacles, but only a few knew that these are the eyes. Every-one who named the foot (sole) also mentioned its undulating fringe.

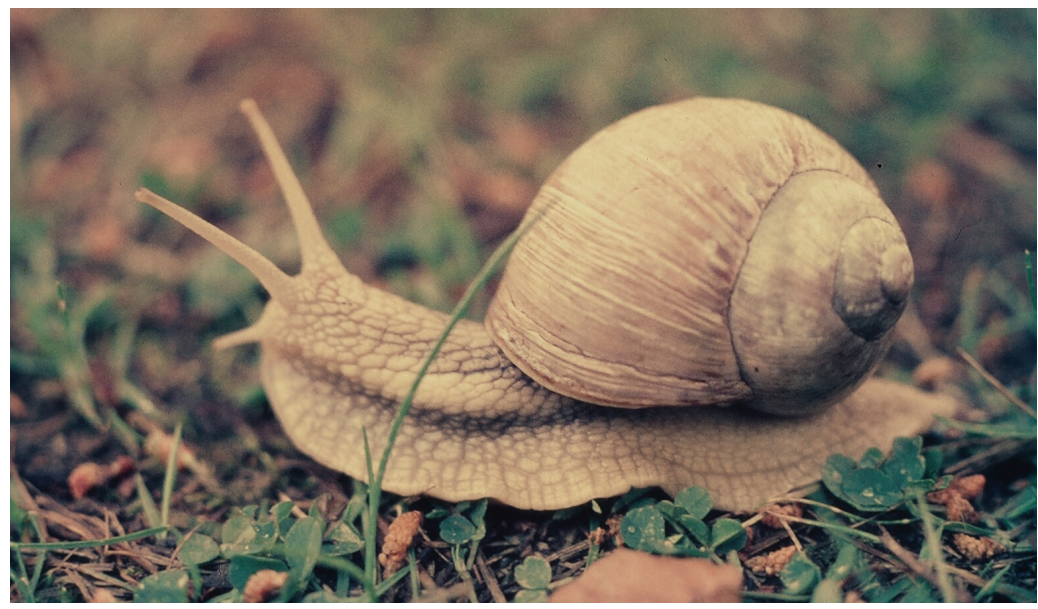

Fig. 1. The vineyard snail (Helix pomatia).

Table 2. The frequency and order of details seen by primary teacher students in the picture of the vineyard snail.

\begin{tabular}{|l|l|l|}
\hline Item or detail & $\begin{array}{l}\text { Frequency of } \\
\text { mention }\end{array}$ & Mean order in the list \\
\hline 1. Snail (the whole animal) & 50 & 1.2 \\
\hline 2. Longer tentacles & 48 & 3.1 \\
\hline 3. Shell & 47 & 3.1 \\
\hline 4. White clover leaves & 41 & 6.3 \\
\hline 5. Longer grass straw in foreground & 37 & 5.5 \\
\hline 6. Tubercles of skin & 32 & 6.3 \\
\hline 7. Fallen brown leaf in the foreground & 24 & 7.8 \\
\hline 8. Lawn & 23 & 6.4 \\
\hline 9. Light brown colour of the animal & 21 & 7.0 \\
\hline 10. Foot (sole and the undulating foot-fringe) & 21 & 7.3 \\
\hline 11. Pine needles on the ground & 20 & 8.3 \\
\hline 12. Fallen catkins on the ground & 20 & 8.4 \\
\hline 13. Smaller tentacles & 19 & 6.5 \\
\hline 14. Growth lines of the shell & 18 & 7.2 \\
\hline 15. Soil & 16 & 7.6 \\
\hline 16. Spiral structure of the shell & 15 & 7.1 \\
\hline 17. Dewdrops & 15 & 8.3 \\
\hline 18. The knobs in the of longer tentacles (eye-spots) & 12 & 7.3 \\
\hline 19. The misty background of the picture & 9 & 7.7 \\
\hline 20. Pieces of thin twigs on the ground & 9 & 8.7 \\
\hline 21. Dead hay straw & 3 & 9.0 \\
\hline 22. Small stones & 2 & 10.5 \\
\hline & & \\
\hline
\end{tabular}


All 50 students mentioned the whole animal and it was first in the list for 46 students. Almost all mentioned the longer tentacles and the shell. In reading the picture the first thing is to find out what it is. The snail schema is then activated in the memory. I think that this schema is constructed from the general outline of the animal and maybe the non-segmented body (no one mentioned this feature separately). From the snail schema in the mind, people pick out some important diagnostic features, of which the most important seem to be tentacles and shell. These features are first checked to confirm the identification. After this other features are scanned. The list order is roughly the same for all students.

The order of observing details seems to proceed from foreground to background, although in this picture the background is blurred. It is well documented in research that details in the foreground are seen more often (Reid, 1990a), thus explaining why white clover leaves, one prominent blade of grass, and a brown leaf were high up on the list. According to this list the scanning of the picture seems to proceed from the centre to the margins perhaps depending on the composition of this picture. According to Hatva (1987) the order of scanning proceeds from the corners and edges to the centre.

The list above (Table 2.) belongs to the direct cognitive cell of Table 1. From there teachers and textbooks usually proceed to the indirect cognitive cell where the picture is further read with the help of theories and generalizations. The affective domain is usually left out in science teaching, but the four-field method implies its treatment. The four-field analysis of the snail picture is shown in Table 3. It is a generalized summary of the work and classroom discussion of many student groups during the course. Only a short list of topics discussed during the course is given, but it is possible to proceed much deeper in any of the cells.

Students' knowledge of the biology of snails was meagre and that is why the indirect cognitive cell was the most difficult for the students. The direct affective cell was the easiest. The cultural meanings cell was fairly easy but needed classroom discussion. In the subject of biology cultural meanings are usually not central, contrary to history, geography (see e.g. Rose, 2008), and arts. Usually pictures in biology and geography teaching are used as unproblematic illustrations, although biology is also closely associated with political and cultural meanings (e.g. Trommer, 1993).

Table 3. A four-field analysis of the picture of the vineyard snail.

\begin{tabular}{|c|c|c|}
\hline & Cognitive & Affective \\
\hline Direct observations & $\begin{array}{l}\text { Spiral shell, two pairs of antennae, } \\
\text { slimy skin, nodules on skin, stripes } \\
\text { on the shell, grass, etc. }\end{array}$ & Charming, disgusting, interesting \\
\hline Indirect observations & $\begin{array}{l}\text { Mollusc. Eyes on tip of the anten- } \\
\text { nae. Herbivore. Needs moisture. } \\
\text { Hermaphrodite. Withdraws into } \\
\text { the shell during adverse weather } \\
\text { or if enemies are threatening. The } \\
\text { growth of the shell. Locomotion. }\end{array}$ & $\begin{array}{l}\text { Symbol of slowness. Foreteller of } \\
\text { rain in Finnish folklore. Delicacy in } \\
\text { some areas but rejected as a food in } \\
\text { Finland. A pest in gardening. Snail as } \\
\text { a character in stories. }\end{array}$ \\
\hline
\end{tabular}




\section{THE USE OF THE FOUR-FIELD METHOD OF ANALYSING PICTURES IN PLANNING TEACHING}

\section{Choosing and using the knowledge structures}

While looking at the cognitive domain of the picture directly observable features are usually treated first. To advance towards understanding, some central knowledge structure is needed, which gives meaning to the details. There are of course many possible knowledge structures depending on the particular case. In the case of animals and plants in introductory biology teaching two knowledge structures usually prevail. One is the systematic knowledge structure: an organism is treated as a representative of a larger group, in the case of the snail, mollusc and gastropod. Mollusc features include a soft moist body without backbone, no segmentation and a limy shell. Another widely applicable knowledge structure is ecological. How have the main problems of survival been solved? These include especially energy supply, avoidance of enemies, and survival in adverse weather, reproduction, and dispersal, which together form a coherent strategy (Applegate, 1993).

\section{Planning the classroom discussion and questioning strategies}

The next phase of the planning for using a picture in teaching is planning the classroom discussion. First, it should be decided whether to start from the cognitive or the affective domain. To arouse interest it is good to start from the direct affective reactions, because these are what first come to mind. The teacher can use this to arouse interest and these evoked feelings also help in remembering things. In this paper I shall not go into further details on this aspect. I refer readers to an excellent book by Harlen and Qualter (2004). The book focuses on primary science but the principles given are also applicable to secondary school. A good article by Yip (2004) is concerned with questioning for conceptual change. The two publications, like most guides on science teaching, treat the cognitive aspects of questioning, and only a few books include the affective domain, e.g. Steinberg (1976) and Knapp (1992). The most vital thing in planning the use of pictures and other teaching material is the intended teaching functions. Teaching functions also largely determine the questioning strategies.

\section{Planning the teaching functions of pictures}

According to Pozzer and Roth (2003) the functions of photographs in biology textbook are divided into four classes: decorative, illustrative, explanatory, and complementary. The classification of Reid (1990a) is much longer. The actual functions of pictures in classroom teaching are far more diverse, and teachers vary these according to context, learning objectives, and target group. Unfortunately authentic classroom studies on this question are missing.

Teachers select pictures for several educational purposes, which can be roughly divided into cognitive (relating to the content) and affective (relating to the feelings and personal or social meanings). This division is not clear-cut, because in many teaching acts the affective and cognitive functions fuse. According to Hannus (1996) the main affective functions are to 1) evoke feelings suitable for learning, and 2) convey attitudes and values. The main cognitive functions are to 1) direct attention, 2) make recall easier, and 3) increase understanding. Hannus believes that other proposed functions are subdivisions or specifications of these five main functions. The list below is mainly adopted from Hannus (1996), but some details are added from Reid (1990a) and Hatva (1987). This list should not be considered as exhaustive and definitive, but rather as a tentative check list helping teachers in their planning. It does not matter if different people understand it differently, since its main function is to make a teacher's actions more deliberate. A detailed analysis of these categories is beyond the scope of this article and the reader is referred to the literature cited. 


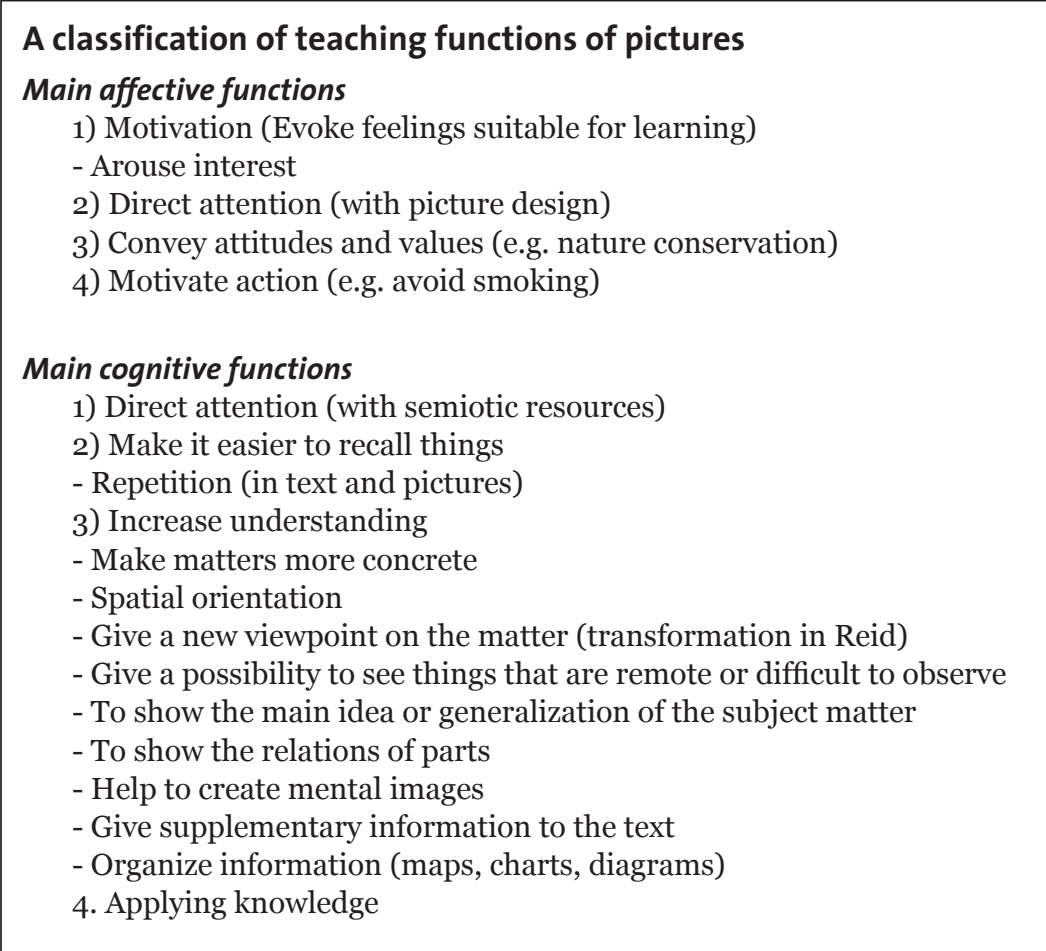

\section{An application exercise}

The next phase in the course was to apply the knowledge to a new situation through teamwork. Students were divided into small groups and they were given a selection of textbooks, which were combined science textbooks. They analyzed one picture according to the assignment instructions below. The results were presented to the others and discussed together. This exercise summed up the course unit and tied it to the teacher's main professional skills. After one exemplary analysis (the snail picture) students could fairly easily apply the analysing principle to a whole range of different types of pictures in combined science textbooks (physics, chemistry, biology, geography and health education). Some student groups succeeded almost without help but others needed guidance. This was partly dependent on the selected pictures, because the content and possible teaching functions were more obvious in some pictures than in others. Each group presented their work and the results were discussed together. Unfortunately the students' works were not systematically collected and documented and there was also no follow-up study afterwards.

\section{Student assignment}

1. Choose one picture, which you think is good in teaching.

2. Analyze the picture by using the four-field method.

3. Choose and plan the main knowledge structure to be taught.

4. Choose and plan the teaching functions used with this picture.

5. Plan the questions for classroom discussion. 


\section{A summary of some research findings to guide the student teacher in the use of pictures in the classroom}

The course unit ended with a short summary of important research findings on the effects of pictures on learning. This was considered important because in many cases teachers' thinking about the effect of pictures on learning is contrary to research findings (Cook, 2006). This was the case among my students, too. These points were discussed together and in the majority of cases students' prior knowledge was false.

The content of this unit is given in other parts of the article, especially in the introduction. A very important source was the review article by Cook (2006), where the most critical points are given in a table. The length of this part of the course unit depended on the time available and the interests of the students. This was conducted as a classroom discussion, where the emphasis was on the picture and text (and teacher talk) interaction.

\section{Discussion}

Compared to reading comprehension of text, knowledge about learning from pictures is very limited (e.g. Schlag \& Ploetzner, 2011), which is why teachers' ability to use pictures in teaching is poor and the reading of pictures is rarely taught. There is a shortage of learning strategies for picture comprehension (Schlag \& Ploetzner, 2011). Common sense thinking of teachers about pictures is also largely contrary to research findings (Cook, 2006). Teaching from pictures is mostly done in the cognitive framework only and affective and cultural domains are avoided. However, practically all illustrations contain cultural aspects, something which is better understood in history, geography and social sciences than in science teaching.

Phenomenological thinking about human experience is the starting point of this study. Phenomenology is considered a very difficult subject yet the basic principles are not very difficult to acquire, although the conclusions are often contrary to everyday thinking. There is no single truth about phenomenology and people can use their own ideas within this framework (Wagner 1983). Human experience is seen as a whole, bodily and multisensory. Experience is the humans interface to the world. If we apply this principle to education, feelings and personal and social meanings should be treated together with factual knowledge, because all these aspects are integrated in the memory. This bodily foundation of the existence of human people is almost totally ignored by science educators, which means for instance that intersubjectivity cannot be treated adequately (Sages \& Szybek, 2000).

The idea of the method developed in this study has its origin in art history and aesthetics, from where it was adapted, for instance, to human geography. The three-layer analysis (objective, subjective and representational layers) of seeing by Karjalainen and Raivo (1995) is very helpful and widely applicable. I have used it with my students for studying urban and rural places, landscapes, buildings, interiors and photographs. The students adopted it fairly easily, although this kind of thinking was new to them. In this article a somewhat more complicated four-field analytical tool is given to promote the meaningful reading of pictures and to help to plan the use of pictures in teaching. There are two dichotomies in the four-field: direct / indirect and cognitive / affective observations. For the best result all the aspects shown in the four-field method should be integrated. This calls for more integration between science and other school subjects.

With the four-field method I also want to stress the importance of the affective domain as equal to the cognitive domain in science teaching. It connects emotions and personal and social meanings to factual knowledge and knowledge structures. In this way it is easier to make learning personally meaningful and increase the possibility of more lasting knowledge structures. This principle is shared by several alternative educational movements: e.g. confluent education (Brown, 1971; Steinberg, 1976), holistic education (Miller, Cassie, \& Drake, 1990) and humanistic education (Knapp \& Goodman, 
1983; Knapp, 1992). These affective teaching methods have always remained marginal but I would like to revive these ideas. Research is needed to reveal the effect of affective approaches on recalling and comprehension. To my mind this approach is also in harmony with the Science, Technology, and Society (STS)-approach in science education, which puts emphasis on decision making and the consequences of science and technology issues for social (and personal) affairs (e.g. Mansour, 2009).

Pictures can be used for a multitude of purposes in teaching. These purposes can be divided into cognitive and affective, of which the latter slightly prevail. This paper gives a classification of the teaching functions of pictures. To make teaching from pictures more effective teachers should be aware of the educational purposes of using the picture. These purposes guide the classroom discussion. The presented list should be considered tentative, because authentic classroom research on this subject is missing. I hope that this article will encourage teacher educators to study this question further.

I think that the most important benefit of the four-field method is that it helps the teacher to plan teaching in several ways. It clarifies many aspects of the pictures as well as of the text. It helps, for example, to clarify the content and picture - text interaction, to foresee the emotional reactions of students, to reveal the possible connections of the content to personal and social issues, to structure the lesson and to plan discussion questions. In short, it helps the teacher to see natural connections between pedagogy and the content.

When I used and developed this method for over a decade, students were usually enthusiastic. After the lesson they often remained behind for comments and discussion and said that this was something new and very interesting to them. Unfortunately the effectiveness of the method was not tested, and I hope that someone else would do it. One reason was that it was only afterwards that I had the opportunity to learn the theoretical foundations of phenomenology.

The four-field method is supposed to be a tool for the teacher and I have not used it with pupils, although the simpler three-layer method might be suitable for pupil use. These methods can be used in the way I have done, but I hope that this article will encourage teachers and teacher educators to develop their own methods and report them. It should be remembered that the method I present here is only one of the endlessly possible ways of looking at pictures, which suggests that only unstable and fragmentary structures can be found. It is impossible to form a coherent theory of pictures (Mitchell, 1995, p. 420).

\section{ACKNOWLEDGEMENTS}

I am grateful to Dr. Tiina Silander, head of the Department of Teacher Education, University of Jyväskylä, for offering me working facilities after retirement. I also thank prof. Jouni Viiri for useful criticism and encouragement.

\section{REFERENCES}

Adams, W. W. (1999). The interpretation of self and world: Empirical research, existential phenomenology, and transpersonal psychology. Journal of Phenomenological Psychology, 30(2), 39-65.

Applegate, J. (1993). Species as systems. American Biology Teacher, 55(7), 392-398.

Berleant, A. (2000, orig. 1970). The aesthetic field: A phenomenology of aesthetic experience. Christchurch, N.Z.: Cypereditions Corp.

Brown, G. (1971). Human teaching for human learning. An introduction to confluent education. New York: Viking Press.

Cook, M. P. (2006). Visual representations in science education: the influence of prior knowledge and cognitive load theory on instructional design principles. Science Education, 9o(3), 1073-1091.

Cosgrove, D. \& Daniels, S. (Ed.) 1989. The iconology of landscape: essays on the symbolic representation and use of past environments. Cambridge: Cambridge Univ. Press. 
Florax, M., \& Ploetzner, R. (2010). What contributes to the split-attention effect? The role of text segmentation, picture labelling, and spatial proximity. Learning and Instruction, 2O(3), 216-224.

Harlen, W., \& Qualter, A. (2004). The teaching of science in primary schools. 4. ed. London: David Fulton.

Hannus, M. (1996). Oppikirjan kuvitus: koriste vai ymmärtämisen apu. Turun yliopiston julkaisuja C 122.

Hatva, A. (1987). Kuva - hyvä renki, huono isäntä. Porvoo: Oy Urex.

Karjalainen, P. (1986). Geodiversity as a lived world: on the geography of existence. University of Joensuu (Finland). Publications in Social Sciences no 7. 190 p.

Karjalainen, P. T., \& Raivo, P. J. (1995). Johdatusta kulttuurimaantieteelliseen maisematutkimukseen. Oulun yliopiston maantieteen laitos. Opetusmoniste 21.

Kearnsey, J., \& Turner, S. (1999). How useful are figures in school biology textbooks. Journal of Biological Education, 33(2), 87-94.

Knapp, C. E. (1992). Lasting lessons: A teacher's guide to reflecting on experience. Charleston, WV: Eric Clearinghouse on Rural Education and small Schools.

Knapp, C. E. \& Goodman, J. (1983). Humanizing environmental education: A guide for leading nature and human nature activities. Martinsville, Ind.: American Camping Association.

Lefebvre, H. (2002). The production of space. Oxford: Blackwell.

Mayer, R. E. \& Massa, L. (2003). The three facets of visual and verbal learners: Cognitive ability, cognitive style, and learning preference. Journal of Educational Psychology, 95(4), 833-841.

Mansour, N. (2007). Challenges to STS education: Implications for science teacher education. Bulletin of Science, Technology \& Society, 27(6), 482-497.

Mansour, N. (2009). Science - Technology - Society (STS): A new paradigm in science education. Bulletin of Science, Technology \& Society, 29(4), 287-297.

Miller, J. P., Cassie, J. R. B., \& Drake, S. M. (1990). Holistic Learning: A teacher's guide to integrated studies. Toronto: OISE Press.

Mitchell, W. J. T. 1995. Picture theory. Chicago: Chicago Univ. Press.

Moran, D. (2000). Introduction to phenomenology. London and New York: Routledge

Panofsky, E. 1972: Studies in iconology. Humanistic themes in the art of the Renaissance. New York: Harper \& Row. Icon Edition

Pink, S. (2011). A multisensory approach to visual methods. In: Margolis, E. \& Pauwell, L. (Ed.). The SAGE handbook of visual research methods. Chapter 31.

Pozzer, L. L., \& Roth W-M. (2003). Prevalence, function, and structure of photographs in high school biology textbooks. Journal of Research in Science Teaching, 40(10), 1089-1114.

Pozzer-Ardenghi, L., \& Roth W-M. (2005). Making sense of photographs. Science Education, 89(2), 219-241.

Rasch, T., \& Schnotz, W. (2009). Interactive and non-interactive pictures in multimedia learning environments: effects on learning outcomes and learning efficiency. Learning and Instruction, 19(5), 411-422.

Reid, D. (1990a). The role of pictures in learning biology: Part 1, perception and observation. Journal of Biological Education, 24(3), 161-172.

Reid, D. (1990b). The role of pictures in learning biology: Part 2, picture-text processing. Journal of Biological Education, 24(4), 251-258.

Reid, D. J., \& Miller, G. J. A. (1980). Pupil's perception of biological pictures and its implications for readability studies of biology textbooks. Journal of Biological Education, 14(1), 59-69.

Rose, G. (2008). Using photographs as illustrations in human geography. Journal of Geography in Higher Education. 32(1), 151-160.

Sages, R., \& Szybek, P. (2000). A phenomenological study of students' knowledge of biology in a Swedish comprehensive school. Journal of Phenomenological Psychology, 31(2), 155-187.

Salomon, G. (1984). Television is easy and print is tough: The differential investment of mental effort in learning as a function of perceptions and attributions. Journal of Educational Psychology 76 , 647-658. 
Schlag, S., \& Ploetzner, R. (2011). Supporting learning from illustrated texts: conceptualizing and evaluating a learning strategy. Instructional Science 39(6), 921-937.

Seufert, T. (2003). Supporting coherence formation in learning from multiple representations. Learning and Instruction, 13(2), 227-237.

Smith, J. A., Flowers, P. \& Larkin, M. (2009). Interpretative Phenomenological Analysis. London: Sage.

Staver, J. R. (1998). Constructivism: Sound theory for explicating the practice of science teaching. Journal of Research in Science Teaching, 35(5), 501-520.

Steinberg, J. M. (1976). Emotional growth in the classroom: Implementing affective education through the process of confluency. Uppsala: University of Uppsala Press.

Trommer, G. (1993). Natur im Kopf: die Geschichte ökologisch bedeutsamer Naturvostellungen in deutschen Bildungskonzepten. 2. Aufl. Weinheim: Deutscher Studien Verlag.

Tuan, Yi-Fu (1977). Space and place: the perspective of experience. London: Edward Arnold.

Tuan, Yi-Fu (1979). Sight and pictures. Geographical Review. 69(4) 413-422.

Wagner, H. R. (1983). Phenomenology of consciousness and sociology of life-world. Alberta: University of Alberta Press.

Yip, D. C. (2004). Questioning skills for conceptual change in science instruction. Journal of Biological Education, 38(2), 76-83. 